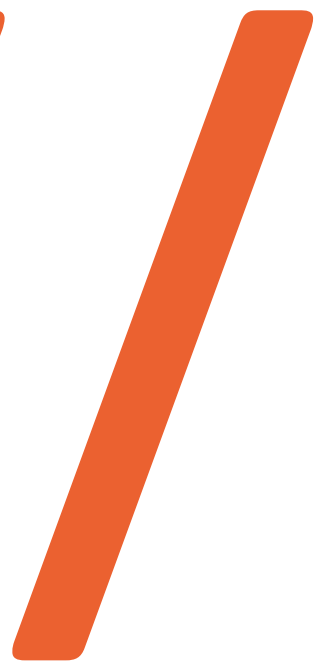

\title{
Luis Buñuel:
}

\section{uma poética do selvagem ${ }^{1}$}

I/I/I/I/I/IIII Eduardo Peñuela Cañizal

UNIP/USP

1. Este trabalho faz parte de projeto de pesquisa que realizo com bolsa do CNPq. O texto, com algumas modificações, corresponde ao da comunicação apresentada ao GT Fotografia, Cinema e Vídeo, no XVIII Encontro Anual da COMPÓS, junho de 2009. 


\section{Resumo}

Este artículo é uma análise do efeito das rupturas retóricas no nível da trilha sonora e do enxerto de imagens em filmes de Luis Buñuel. Seu principal objetivo é estudar o papel que esses recursos têm numa poética do selvagem.

\section{Palavras-chave}

Abstract

This article is an analysis of the effect of rhetorical disruptions at the levels of soundtrack and images inserts in Luis Buñuel's films. Its main objective consists in detaching fragments of films with the finality of studying the role of a wild poetics.

\section{Key-words}


Figura 1
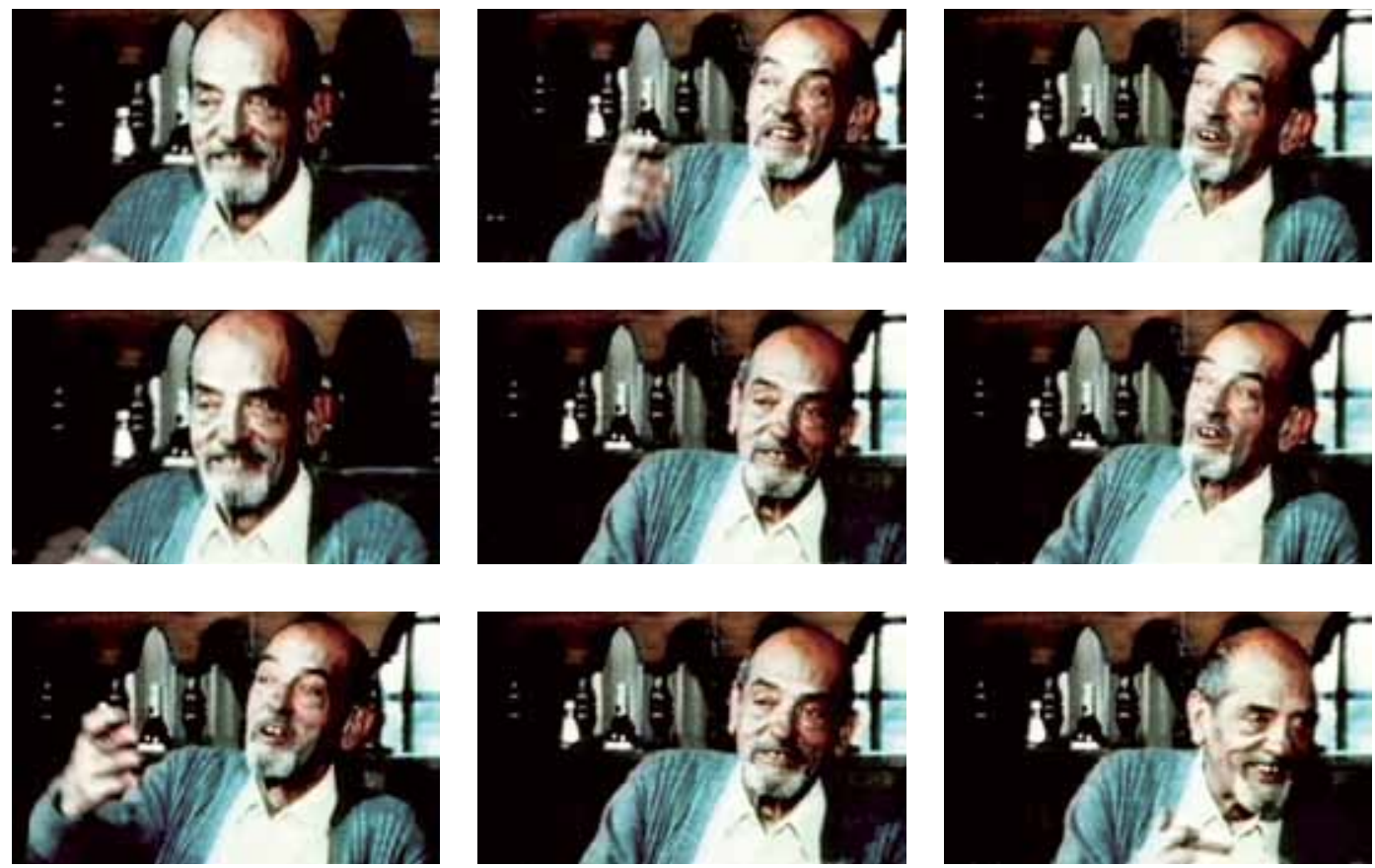

2. Não vejo a traquéia, a faringe, a glote, a cavidade nasal ou o palato duro, para não citar outros.

Numa das sequências de um documentário reproduzido fragmentariamente na fita A propósito de Luis Buñuel (2000), o cineasta, no palco do seu rosto, encena gestos e fonações que me intrigam. Nas toscas imagens da sequência em que Buñuel inventa um relato surrealista- Figura 1 -, os lábios e os dentes do diretor se movimentam no entremeio da confiança de quem diz o que deseja e da convicção de quem deseja que o dito adquira um determinado tono. Esses visíveis personagens da morfologia corporal combinam suas ações com as de outros personagens bucais que o espectador não vê ${ }^{2}$, por conseguinte, não percebe as contribuições que eles fazem durante a fala. Tudo indica, entretanto, que esses personagens-órgãos são responsáveis diretos por um trabalho de inervação cujos resultados se deixam sentir nas imagens sonoras da fala, nessa espécie de trilha fônica em que um componente tão complexo como a representação de palavra intervém.

Para se avaliar o grau de complexidade de tal representação pensemos na operação que um usuário da língua portuguesa tem de fazer quando pronuncia uma palavra ou elabora uma frase. Um fa- 
lante deste idioma, ao proferir, por exemplo, o substantivo montanha associa a imagem sonora a um sentimento de inervação de palavra e, assim, o falante passa a ser sujeito de uma espécie de pós-fala - um ato de fala em que se repete o dito por outrem -. Esse é o caminho que, segundo Freud ${ }^{3}$, conduz ao falar sintático: enlaçamos as palavras entre si e para completar a frase com uma nova palavra será necessário levar em conta a inervação da última palavra dita e aguardar a chegada da imagem sonora da palavra a ser incorporada. Contudo, a inervação não é algo exclusivo da palavra. Ela também age na escrita, entendida simplesmente como sistema alfabético ou como artifício de inscrever imagens num suporte apropriado. O processo é semelhante e suas conseqüências no trabalho de leitura podem ser extraordinariamente significativas ${ }^{4}$. Há vestígios importantíssimos da inervação na grafia de uma letra ou, mesmo, na camada sensível de uma película, pois não se deve menosprezar a idéia de que uma fotografia, por exemplo, começa com o disparo de uma câmera produzido, no geral, por um aperto do dedo indicador ${ }^{5}$.

Os fotogramas transcritos na Figura 1 se reportam a um conjunto de planos em que Luis Buñuel conta um relato singular. Uma pequena anedota, inventada por ele mesmo, para construir uma fábula exemplar sobre o que significa ser ateu e os matizes que esse estado pode assumir num trajeto que vai do sorriso ao riso. O cineasta aí imagina que, na hora da sua morte, reunirá seus melhores amigos - comunistas e descrentes - para que ouçam seu testamento ideológico através da confissão que ele fará a um padre da sua confiança. Declarará em voz alta que ele acredita piamente em Deus e se arrepende de todos os seus pecados nefastos, pedindo aos que assistem ao ato que tomem sua morte como exemplo. Seus amigos ficarão horririzados ao terem sido envolvidos nessa situação. Rindo de si mesmo, Buñuel termina sua historíola vendo-se no fogo eterno por ter tramado semelhante brincadeira. $\mathrm{O}$ saboroso da inventiva não advém exclusivamente do conteúdo das peripécias, mas também da maneira hilariante de narrar: o cineasta degusta as palavras e toda a sua pósfala parece que se vai maquinando com o intuito de romper com o já dito e fazer com que a inervação dos gestos expresse o prazer de quem sabe estar elaborando uma espécie de parábola libertária.

A tendência à subversão é uma constante tanto na obra quanto em muitos dos comportamentos deste criador de sonhos, fascinado sempre pela possibilidade de transformar a pacata sensatez do sorriso na liberadora mordacidade do riso. Enquanto vestígio primitivo de
3. Faço um uso não muito rigoroso do pensamento que Freud formula num pequeno escrito intitulado Palabray Cosa (1993: p.207-212).

4. Exploro alguns aspectos desta questão na leitura que faço de Citizen Kane. Cf. Peñuela Cañizal (2008).

5. Nos meses de outubro e novembro de 2008, o Centro Nacional de las Artes, de México, celebrou a exposição Buñuel entre dos mundos. No catálogo encontramos informações que podem nos servir para explicar melhor o processo de inervação de imagens. A primeira seção desta exposição está dedicada à exibição de fotos feitas pelo cineasta no intuito de compreender a fundo os espaços marginalizados - urbanos e rurais - do México e, também, com o propósito de escolher a localização de cenas de seus filmes mexicanos. Muitas dessas fotos reaparecem, com enquadramentos muito parecidos, em seus filmes da fase mexicana. Assim, para dar tão somente um exemplo, veremos a árvore da fazenda San Francisco de Cuadra que "inspirou” os planos de apresentação do filme Abismos de Pasión. Creio que essas fotos são, em relação com o filme a que elas se vinculam, representações imagéticas nas quais, de certa maneira, encarna um sentimento de inervação a partir do qual as sequências fílmicas onde se "repetem" se impregnam, enquanto representações "ditas", das reminiscências de algo embrionário: tema sempre presente nos momentos mais marcantes do cinema de Buñuel. 
6. O termo escripção é por mim usado na acepção que lhe confere Roland Barthes quando, em várias passagens da sua obra, destaca o compromisso da escrita com o trabalho manual, com as rasuras do estilete sobre a superfície que venha a ser usada na condição de suporte. Se pensarmos que a fotografia nasce das marcas que deixa a luz na superfície de um corpo sensível e que a produção do som implica na utilização de várias partes do corpo, a escrita fílmica tem sua origem na escripção entendida como inscrição. Recomendo, a quem se interesse pelos matizes desta questão, a leitura da coletânea de textos de Barthes sobre este assunto reunidos em Variaciones sobre la escritura (2002) uma atitude agressiva domesticada pelo animal humano, o sorriso pode se transformar, paulatinamente, na subversão de uma gargalhada. Criando tensões entre esses dois pólos, o cineasta - como pretendo mostrar neste trabalho - constrói uma poética do selvagem para tumultuar aspectos da escripção ${ }^{6}$ fílmica feita mediante combinatórias expressivas em que imagens e sons se interpenetram e buscam, com essa simbiose, as raízes do originário. Uma poética ancorada no princípio retórico da ruptura utilizada enquanto meio de desfigurar as formas expressivo-semânticas dos falares sintáticos consagrados pelo hábito e, no caso, procurar no entremeio dessas desfigurações vestígios do primitivo, ressonâncias do embrionário e das pulsões do instinto.

Não deve causar surpresa que o cineasta tire proveito de suas "petites histoires" e que em muitas ocasiões as utilize dando-lhes uma nuança jocosa. No entanto, quem melhor traduz e interpreta esse traço é o romancista chicano John Rechy (1999: p.34-9). Este escritor, alimentando sua imaginação com boatos, elabora um delicioso texto de ficção em que os sons das palavras e a conhecida surdez de Buñuel tecem instigantes mal-entendidos. Um deles se engendra do encontro havido entre o cineasta e Marilyn Monroe durante as filmagens de El Angel Exterminador. Segundo o narrador, a atriz estava acostumada a que lhe fizessem perguntas banais - por exemplo, sobre o sabonete usado ao tomar banho antes de dormir - e esperava, fazia tempo, que alguém lhe fizesse uma pergunta diferente, como a feita por Buñuel quando ele quis saber o que ela pensava da vida. $\mathrm{E}$, como se diz ter assistido à filmagem de uma das cenas em que as personagens falam sem parar sentadas à mesa, ela teria respondido: “A vida é um enorme sem sentido.....falando (talking), todos falando ao mesmo tempo... inconscientemente (obliviously)." E ao dizer isso, a atriz lembrou que a primeira vez que usou obliviously - ainda não era casada com Arthur Miller -foi corrigida pelo dramaturgo, quem a intimou a dizer obviously.

A autoritária correção de Arthur Miller carecia de fundamento e Buñuel, anos mais tarde, nas filmagens de Le Discret Charme de la Bourgeoisie, recorda, ao ver a cena em que as personagens caminham sem rumo, a frase de Marilyn e, entusiasmado, exclama: "Dedico este filme à la hermosa y brillante Marilyn Monroe!" Mas o assistente - Pierre Lary -, julgando que tudo era fruto de um equívoco provocado pela surdez de Buñuel, houve por bem colocar as coisas em seu lugar e se dirigiu ao cineasta para informar-lhe que a 
estrela tinha dito "talking” (falando) e não "walking” (caminhando). Mal sabia ele que a questão não era essa: o motivo que levou Buñuel a tal dedicatória vinha do discreto encanto da palavra obliviously encenada na bela boca de Marilyn Monroe. O mistério se engendrou na insólita combinatória em que uma forma sonora ambígua de per si se acopla a uma excitante imagem carnal. Essa talvez seja uma das interpretações mais belas e profundas do cinema poético de Luis Buñuel 7 , sobretudo se a avaliarmos no contexto da pós-fala e do falar sintático. Não há dúvida de que Buñuel constrói uma complexa metáfora através do processo de substituir o já dito pelo ainda não dito. Um tipo de tropo cuja índole surrealista se faz sentir num processo de associação semelhante ao desencadeado pelo trabalho do sonho com base no estabelecimento de relações analógicas entre o dito na véspera e o não dito a que o sonho enigmaticamente se refere. Nesse jogo arraiga o poder subversor da poética de Buñuel, sempre direcionada, através de seus atentados contra a lógica e o lugar comum, no rumo de libertar as energias do instinto.

As experimentações levadas a cabo no trabalho de sincronização de elementos do som e das imagens formam, no domínio poético do audiovisual, um campo de indagação particularmente atraente. Não só pela complexidade dos objetos que o integram, mas também porque a elaboração desses objetos decorre, em muitos casos, de práticas inovadoras e revolucionárias. A esse respeito, vale a pena se deter nalguns dos resultados conseguidos em Belle de Jour, considerado um dos filmes mais populares de Buñuel e, supostamente, uma obra de fácil compreensão. O sucesso deste filme é um dado incontestável. Mas, no atinente à compreensão, o assunto muda de rumo a partir do instante em que o espectador percebe que, nesta obra, o texto foi estruturado seguindo o ardil de confundir cenas atreladas à vida social com cenas comprometidas com o mundo interior dos sonhos. Tal sorte de estratagema constitui, sem dúvida, um atentado contra as plataformas em que se alicerçam as colunas de uma narrativa tradicional. E vai mais longe se tomarmos consciência de que ele é também uma ferramenta poética capaz de abalar as estruturas construídas perversamente para acobertar como verdades indiscutíveis as sectárias inverdades veiculadas por requintados dispositivos postos irrestritamente a serviço do mundo artificial da informação.

Vem daí a força corrosiva que vai pouco a pouco enferrujando a engrenagem que movimenta ordenadamente as concatenações determinadas pelo princípio de causa e efeito. Por isso, diante de
7. Freddy Buache (1970: p.59-60) foi um dos primeiros em chamar a atenção para o poder de sugestão das “ boutades” de Buñuel e a valorização, por esse meio, de fatos aparentemente insignificantes. No texto da entrevista a Conchita - irmã do cineasta transcrito por Max Aub em seu livro Conversaciones con Buñuel (1984: p.177) se faz menção a um episódio saboroso: para se livrar de uma namorada a quem tinha prometido casamento, o jovem Buñuel "inventa” a existência um amigo que escreve uma carta comunicando à moçoila que seu namorado tinha perdido a vida num grave acidente de moto. O sarcasmo de fantasias desta índole aparece em muitos dos seus filmes. 
uma imagem e do som que a acompanha, o espectador se vê amiúde aturdido e, longe de ter certeza do significado palpável daquilo que está contemplando, se perde nas incógnitas da ambigüidade. Esse desconcerto aumenta porque, como muito bem assinala Harmony $\mathrm{H}$. Wu, Buñuel se entrega à ironia e ao rompimento das normas utilizando as mesmas regras usadas na construção das mundividências que ele deseja destruir:

“... a maneira particular de subverter que se observa em 'Belle de Jour', embora diferente à que se manifesta em 'Un Chien Andalou', se assemelha com a que aparece em 'Le Charme Discret de la Bourgeoisie': trata-se de se opor às convenções da narrativa sem se afastar, porém, das mesmas regras de jogo. As cenas "reais" de Séverine em seu apartamento estão acusticamente marcadas pelo tique-taque e as badaladas dos relógios, sublinhando hiperbolicamente a hipotética "realidade" com a progressão "real" do tempo. A obsessão com o tempo não representa somente a instância mais elevada da estrutura do mundo da burguesia, como acertadamente sugere Evans, mas também a progressão da estrutura fechada do tempo na narrativa convencional." ( 1999: $p .127)^{8}$.

8. A tradução ao português dos fragmentos de obras que constam da referência bibliográfica no idioma original em que foram escritas é da minha responsabilidade.
Em algumas ocasiões, Buñuel apresenta os laços de Séverine com sua vida pregressa através de mediações feitas pela manipulação de signos acústicos. Nos devaneios da personagem, freqüentemente os elementos auditivos antecipam o retorno à vida cotidiana ou a regressão a momentos anteriores ao presente que as imagens designam. Wu destaca várias passagens em que essa técnica é praticada. Assim, quando Séverine-menina está na iminência de ser violada se escuta uma voz que a chama, uma voz cujo ponto de vista é indefinido: não se sabe de onde vem e tampouco se sabe se coincide com o passado ou com o presente da personagem. Signos acústicos como esse são inseridos na transição das imagens e, por esse motivo, geram um clima de ambigüidade que afeta a ordem causal do relato. E, sobretudo, tergiversa a informação a partir da qual o espectador teria a possibilidade de distinguir os atos cotidianos das ações fantasmagóricas decorrentes do trabalho da imaginação ou das fantasias a que amiúde se entrega a Bela da Tarde. Esse tipo de enxerto sonoro atua como um elemento intermediário em que oscilam o dito presente no sentimento da inervação e o repetido da representação de palavra, processo através do qual se geram indefinições que afetam a 
significação das imagens e, conseqüentemente, tornam ainda mais ambíguos seus conteúdos.

Além de formatar simbioses específicas das imagens com o som, esse recurso expande as molduras e as bordas dos enunciados ${ }^{9}$ fílmicos e, por conseguinte, alarga as possibilidades de significação. Tanto é assim que, nesse conjunto de cenas formado pela suposta saída de Séverine do prostíbulo até aquelas em que ela é enlameada e insultada por Pierre e Husson, os signos auditivos se desencontram com o que seria uma sincronização "realista" e criam uma ambiência enigmática. No plano fechado em que Séverine aparece ensimesmada, depois de haver queimado suas roupas íntimas, ecoam ressonâncias de sinos que, sinestesicamente, parecem representar os latidos da dor de cabeça fingida pela personagem para justificar, perante o seu marido, sua indisposição para ir jantar fora. Mas, depois de uns segundos, essa impressão se dilui e na tela surgem as imagens de um rebanho de touros escuros. De imediato, os animais se metaforizam no diálogo de Pierre e Husson: passam, de representar o arrependimento, a encarnar a expiação da culpa. Um jogo de palavras mediante o qual se instituem as bases para ampliar os espaços expressivo-semânticos do filme permitindo a entrada de outros textos: no caso, o Angelus, de Millet. A intromissão dessa configuração pictórica faz com que a intertextualidade implantada, vagamente previsíve $^{10}$ nas particularidades da trilha fônica instaurada pelo diálogo de Pierre e Husson, não seja fruto de uma expectativa vinculada aos significados ditos na representação de palavras postas na boca destas duas personagens.

De repente, o bucolismo aparente da cena campestre explode e uma vez rompida essa ordem simbólica entra no palco das ações a violência primitiva de Pierre e Husson: Séverine se transforma no alvo da ira moralista dos dois homens e seu corpo é apedrejado e maculado com punhados de lama amassada. Percebe-se que Buñuel estrutura a concatenação das imagens seguindo um modelo em que a representação dos signos acústicos medeia a junção das imagens, com a particularidade, no entanto, de que a representação de palavra, de per si encadeada com a inervação sonora, não atende à expectativa de um espectador acostumado às normas de um falar sintático habitual. Não se espera o salto de uma imagem mental - a de Séverine com suas preocupações sexuais - para a configuração de uma imagem campestre - a do rebanho de touros escuros -. Nem tampouco se esperava a irrupção de uma trilha fônica em que a ilusão de continuidade acústica se desmorona.
9. Os termos moldura e borda estão sendo aqui usados na acepção que lhes confere o Groupe $\mu$ no livro Traité du Signe Visuel (1992: p. 377-399).

10. Digo vagamente previsível porque, no falar sintático de Pierre e Husson, as palavras arrependimento e expiação não necessariamente exigem a presença de um quadro que complemente e ilustre seus respectivos conteúdos, embora o quadro "simulado" no filme remita a uma obra pictórica de Millet que trata do arrependimento e da expiação 
A ironia atravessa o todo das seqüências em questão e sua mordacidade é, no fundo, iconoclasta. Por trás desse delirante arranjo de imagens e sons se escondem, como nos processos oníricos, sentidos latentes com os que o espectador não atina em suas primeiras tentativas de interpretar este fragmento do texto fílmico. A atmosfera sarcástica se faz, no entanto, perceptível. E, envolvido nela, mesmo o espectador desorientado pelos enigmas das metáforas pressente a força das ações selvagens. Em seqüências destas características, a poesia de Buñuel lança aos campos da imaginação as sementes da ira e, sobretudo, seu permanente desejo de libertação, de arrombar as argolas da moral burguesa e da opressão. Compreende-se que seja este o tipo de arranjo que o cineasta aproveita para introduzir as ambigüidades de suas "boutades" e, também, que tais enxertos auxiliem a leitura uma vez conhecida a origem dos mesmos. A respeito dessa passagem do filme, lembro que Agustín Sánchez Vidal (1991: p. 257) diz ter ouvido de Jean Sorel - ator que encarna a personagem de Pierre - o que se segue:

"Numa sequiência, Michel Piccoli e eu devíamos arrojar punhados de lama sobre o rosto e o corpo de Catherine Deneuve, cobrindo-a também de insultos atrozes, gritando obscenidades muito vulgares e palavrões que a censura não teria permitido. Em lugar de tudo isso, Buñuel nos fez gritar os nomes dos escritores que detestava e durante a filmagem ele ria sem parar."

Evidentemente, enxertos desta natureza não eliminam a riqueza significativa do trecho em questão. Apenas apontam para um rumo possível de leitura, ainda quando não tenham sido mantidos - como é o caso - na versão final da fita. Independente de tais enxertos estarem presentes ou simplesmente aludidos, o procedimento de enxertar desencadeia, sem dúvida, relações de intertextualidade, muitas vezes paródicas até o exagero, que alargam e dão profundidade aos enunciados cinematográficos propriamente ditos. Não raro, eles permitem, por outro lado, a realização de artifícios que acentuam a sua ironia.

Os planos que formam as seqüências finais de Le Journal d'une Femme de Chambre mostram, através de imagens próprias de um documentário de cunho realista, um grupo de manifestantes de extrema direita defendendo aos berros seus slogans ultranacionalistas. Um detalhe, porém, chama a atenção de Freddy Buache. Em sua descrição do episódio, o crítico observa: 
"O cortejo desaparece no fim da rua. Os gritos de "Viva Chiappe" continuam. Na fachada de um prédio, à esquerda, aparece um cartaz em que se promove a marca do aperitivo Picon. O cartaz escamoteia as letras PI. (Talvez se trate de um mero acaso da projeção, o que serviria para mostrar que o acaso nunca é um fenômeno simples!). O resto da palavra é a injúria sorridente que Buñuel dirige ao chefe de polícia cujo nome é uivado por um bando de pequenos burgueses fanatizados, disposto a tudo com tal de que triunfe a mitologia da ordem, da nação, da raça e, no entanto, indiferentes à tarefa de tirar os outros da alienação....". (1970: p.152).
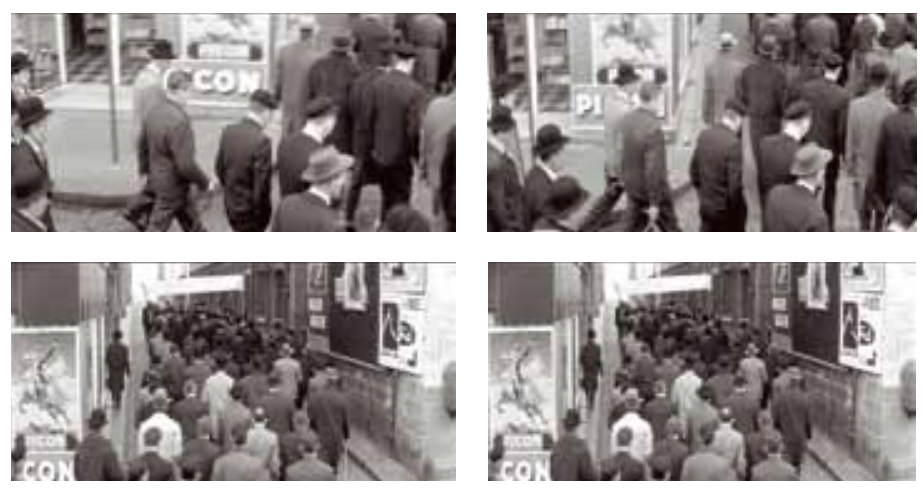

Faz-se necessário, entretanto, prestar alguns esclarecimentos para que o leitor de hoje compreenda melhor o contexto histórico-social em que se situa o comentário de Buache e possa avaliar o alcance de "l'injure souriante" a que se refere o estudioso. Assim, no tocante a Chiappe, o nome do chefe da polícia enaltecido fanaticamente pelos pequenos burgueses tem um antecedente histórico e não é, por conseguinte, uma personagem arbitrariamente inventada por Buñuel para fazer parte, através de signos sonoros, do episódio. Jean Chiappe foi chefe da polícia de Paris, de 1927 a 1934. Foi precisamente ele quem mandou prender as cópias de L'âge d'or em 1930. Ele teve, pois, um papel "relevante" no escândalo causado pelo filme e reunia "méritos" suficientes para receber, portanto, "l'injure souriante". Mas a retribuição de Buñuel a este patriota empedernido, sempre apoiado por grupos de extrema direita, não é tão óbvia quanto se possa imaginar. O cineasta, na última seqüência de Le Journal d'une Femme de Chambre, se valede dois artifícios para expressar ironicamente
Figura 2. Le Journal d'une

Femme de Chambre

(Frames da última seqüência) 
11. Não nego que esta forma de escrita possa ser fruto do acaso. Mas, de qualquer modo, ela se apresenta como elemento concreto do filme, o que permite ao espectador participante organizar sua modalidade de leitura.

Tal procedimento não é alheio à poética de Buñuel, já que esta lida sempre com imagens geradoras de ambigüidade e é nesse núcleo em que se concentram plurivalências significativas onde o leitor pode exercer seu papel interpretante. Não se trata, por conseguinte, de procurar justificativas

nas possíveis intencionalidades do cineasta. Trata-se, isso sim, de levar em conta que a intencionalidade não é propriedade, consciente ou inconsciente, de um autor: ela se engendra,

casualmente ou não, no corpo do texto e é desse corpo que emanam seus significados particulares.

12. O rébus é passível de outras leituras, mas penso que a proposta é suficiente para compreender seu teor. Cabe observar ainda que este recurso já é utilizado por Buñuel em L'âge d'or, o que não impede, porém, que ele seja visto como um possível nexo da obra de Buñuel com procedimentos semelhantes postos em prática por

Godard. Lembre-se, por exemplo, a brincadeira que este cineasta faz com a palavra Ri[vie]ra em Pierrot le Fou. sua vingança. De um lado, os seguidores de Chiappe são representados, com recursos especificamente cinematográficos, pulando como macacos na estreiteza de uma rua que parece não levar a nenhuma parte. De outro, tal qual se pode constatar nos frames da Figura 2, o diretor utiliza um procedimento escritural primitivo ${ }^{11}$ : constrói uma espécie de hieróglifo a partir da grafia da palavra Picon.

$\mathrm{Na}$ caminhada sem sentido dos manifestantes, os indivíduos que passam diante do cartaz do aperitivo fazem com que a palavra se decomponha em PI e CON. O leitor interessado em entrar no jogo instituído poderá armar seu processo de leitura rastreando os indícios dessas duas sílabas. Assim, uma leitura viável nasce do fato de que PI é a transcrição da letra do alfabeto grego $\varpi$ e, em nosso contexto científico-cultural, essa letra simboliza o número irracional mais famoso da história: um número que nunca se completa. Quanto a CON, é só procurar seus significados num bom dicionário de francês e, feita a consulta, obter-se-á a informação de que CON designa "imbecil", "indivíduos idiotizados" ou, num contexto mais vulgar, a acepção pejorativa dada ao órgão sexual feminino para fazer insultos ou exclamações grosseiros. Dessa perspectiva, o isolamento de cada uma das sílabas possibilita a identificação de conteúdos que se escondiam por trás do nome Picon e, em decorrência, a junção dos novos conteúdos descobertos leva o leitor a uma frase do tipo "um bando de seguidores imbecis". ${ }^{12}$

No exemplo de Belle de Jour, os signos acústicos, embora desrespeitando uma sincronização "realista", são percebidos direta e explicitamente pelo espectador. Isso não ocorre na passagem escolhida de Le Journal d'une Femme de Chambre. Nesta fita, a sonoridade do rébus se oferece através de um processo sinestésico: o espectador chega ao som das palavras por vias do visual e, uma vez reconstruído mentalmente esse som, ele "escuta" uma voz que vem do interior da palavra, de igual maneira que Séverine, na cena já comentada, escuta uma voz que vem do seu mundo entranhável. Séverine deixa que o espectador ouça a ressonância da manada dos seus instintos metaforizados no caminhar apinhado dos touros. E o cartaz produz, por sua vez, uma ressonância jocosa que somente o espectador da cena escuta, pois o rebanho de idiotas seguidores de Chiappe caminha sem rumo e não tem condições de ouvir sua própria alienação. Essas duas maneiras diferentes de lidar com os elementos sonoros possuem, entretanto, algo em comum: ambas remetem ao entranhável, ao que, tanto nas coisas quanto nos seres, sobrevive do mundo originário. 
Daí que o espectador atento viva também, diante das combinatórias em que se imbricam as imagens e os sons, as tensões de um conflito poético nascido do confronto entre o centrífugo dos componentes imagéticos e o centrípeto dos componentes acústicos. Porque como defende Jean-Louis Alibert ( 2008: p.18), o olho propende à análise, a fazer um percurso e afastar-se, na direção da abstração, das coisas vistas. Em contrapartida, o ouvido tem a tendência ao global e, com isso, favorece a imersão no campo do sonoro, colocando o sujeito da percepção no "centre d'une boule sonore." Vista na perspectiva freudiana'3 ${ }^{13}$ essa inclinação ao centrípeto se observa também no domínio sonoro da fala, pois, ao sermos donos de um ato de voz passamos a possuir uma representação motriz em que atuam as sensações centrípetas dos órgãos da linguagem. Falar pressupõe, portanto, criar uma inervação de palavra e, ainda, fazer audível em nós mesmos essa inervação, sempre presente, com mais ou menos intensidade, cada vez que exteriorizamos, nos atos de comunicação, a pronúncia da palavra inervada.

Inseridos nesse contexto, os rompimentos poéticos conseguidos por Buñuel em múltiplas combinatórias de imagens e de sons de seus principais filmes evidenciam uma constante preocupação por trazer ao domínio do perceptível os traços originários que se ocultam do outro lado das coisas. Ou seja, explorar recursos retóricos que possuam a capacidade de ultrapassar os limites do espaço emoldurado das imagens associadas à sonoridade. Pouco importa se, em ocasiões, essa associação é motivada ou inconsciente. O relevante, a meu ver, é ampliar o achatamento da superfície em que se plasmam as imagens pela intervenção inovadora de outros elementos materiais: o som, no caso. Essa técnica produz efeitos contundentes pelo fato de que o caráter centrífugo das imagens, responsável por uma ilusão de perspectiva que o cinema herda da pintura, sofre uma alteração radical a partir do instante em que a força centrípeta dos componentes sonoros passa a intervir. Isso fica claro nos dois exemplos rapidamente comentados, mas seu potencial poético se deixa sentir com mais contundência em combinatórias em que, de maneira surpreendente, a inervação sonora arranha a derme das imagens. Esse procedimento não só fragmenta a unidade da narrativa linear, como ocorre em Belle de Jour: ele alarga o horizonte da significação e, com isso, introduze um ominoso efeito de profundidade nos processos de sincronização. Assim, para me deter apenas num exemplo, acontece em La Voie Lactée.
13. Freud trata especificamente deste assunto em seu texto Palabra y Cosa, in Obras Completas, Volume XIV, 1993: p. 207-218, É verdade que Freud analisa aspectos das perturbações afásicas, mas de qualquer modo suas observações sobre a relação simbólica entre a representação-palavra e a representação- objeto são certamente de utilidade para os propósitos deste trabalho. 
La Voie Lactée é um filme, segundo Drouzy (1978), em que não se pretende demonstrar nada. Não é nem um teorema nem uma tese. Mais bem um instigante convite feito ao espectador para que este participe do discreto encanto de um jogo aprazível. Na opinião de Taranger (1990), seu texto funciona com a precisão das parábolas evangélicas, um tipo de escrita onde as metáforas encontram abundantes viveiros e proliferam em ambigüidades para, no fim, agruparse em alegóricas revoadas. Transitam de um lado para outro - dos dogmas até as heresias -, deixando vestígios que remetem a uma complexa inervação dos sentidos responsável pelos não menos complexos mundos da significação. Nas derradeiras páginas de Mi último suspiro (1998: p.297-298), Buñuel não vacila em situar a informação como um dos cavaleiros mais nefastos do apocalipse. Usando metáforas do texto bíblico - ou seja, valendo-se do dito encarnado na representação de palavra -, o cineasta afirma:

"O último roteiro por mim feito - e que nunca chegarei a filmar repousa sobre uma tríplice cumplicidade: ciência, terrorismo, informação. Esta última, apresentada de ordinário como uma conquista, como um benefício e às vezes como um direito, talvez seja, em realidade, o mais pernicioso de nossos cavaleiros (refere-se aos cavaleiros do Apocalipse), pois segue de perto aos outros e só se alimenta de suas ruinas. Se sobre ele caísse de repente uma flecha logo se produziria um descanso do ataque constante em que nos tem subjugados." ${ }^{14}$

14. O roteiro a que Buñuel faz menção é precisamente Agón, escrito em colaboração com Jean-Claude Carrière e publicado pelo Instituto de Estudios Turolenses, Teruel, em 1995 O tema abordado é de uma atualidade impressionante: a vida e as ações de um grupo de terroristas que pretende explodir o Louvre e que a última hora, convencido de que esse ato não causará nenhum impacto, decide desistir.

Na seqüência da Instituição Lamatirne, Jean, um dos peregrinos de La Voie Lactée, imagina, ao escutar a informação modulada com obediência pelas alunas adolescentes do orfanato, um ato terrorista consumado no fuzilamento do Papa que poderia ser realizado por um grupo de jovens revolucionários. Mas Francisco, um dos familiares das meninas que cantam, escuta realmente os disparos do pelotão de execução e, inquieto, pergunta a Jean se tinha conhecimento da existência de alguma pedreira por lá perto. Jean responde que não, que o ruído ouvido era o dos disparos que ele tinha apenas imaginado em sua fanatasia de fuzilar o Papa. Mais uma vez, o enxerto sonoro abala a continuidade das imagens, algo que o cineasta vem preparando para que o espectador se defronte com a ambigüidade na hora de discernir o que acontece na Instituição Lamartine e na mente da personagem. Fica-se com a sensação de que a trilha fônica instituída pelo diálogo das personagens é complementada por aspectos de uma 
trilha sonora em que se privilegia o ruído: os estampidos dos disparos metaforizam um rugido primitivo, uma espécie de rugido animal mediante o qual se instala na cena um clima de inquietação. E não tenho dúvida de que, no caso, esse clima tem suas raízes no ominoso da inervação dos gritos selvagens que rompem, ameaçadoramente, a calma aparente do silêncio protetor.
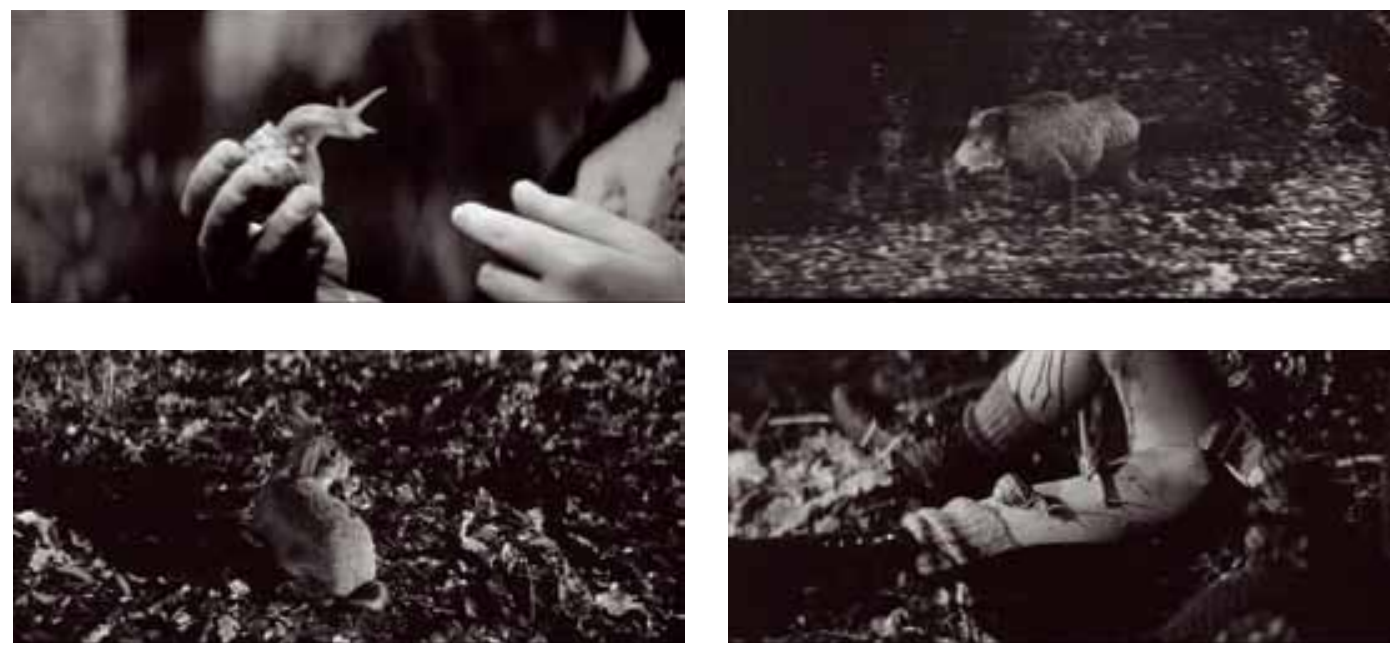

O uso destes recursos de sincronização não só desmantela a estrutura narrativa do cinema clássico e popular, mas se apresenta como uma espécie de atentado poético sobre os conteúdos que os relatos veiculam. Já se sabe que o que mais interessa, no geral, aos espectadores do cinema é a concatenação dos acontecimentos e a informação que o avanço da fábula vai paulatinamente fornecendo. Aos espectadores comuns pouco importam os códigos especificamente cinematográficos - tipo de plano, de lente ou de montagem, por exemplo -. Para eles, o relevante é saber ou ter "informações precisas" do que vai acontecer às personagens, pois são completamente alheios ao fato simbólico de que todo esse processo informativo é fruto de um falar sintático em que a representação de palavra impõe as normas da pósfala. Ou seja, os relatos chamados clássicos e lineares, quase sempre, trabalham sobre dados de uma informação baseada não na inervação de palavra, mas na representação de palavra e, em virtude disso, trabalham habitualmente com algo já dito e, por consequiência, com algo já ouvido. Ao contrário, Buñuel, ao desmantelar a fábula mos-
Figura 3. Fotogramas de Journal d'une femme de chambre 
15. Em seu famoso ensaio sobre o ominoso (unheimlich), publicado em 1919, Freud reconhece que a inquietante estranheza se relaciona com o sentimento de ser despojado dos olhos e, também, com a repetição. Ambas as coisas são muito significativas para estudar alguns aspectos do papel do originário e do primitivo na obra de Buñuel. tra, de um lado, seu inconformismo com a informação e, de outro, seu fascínio pelo originário, por aquilo que ainda não foi dito e se esconde por trás dos sentimentos de inervação. Em soma, as particularidades da trilha sonora e da trilha fônica apontadas colocam em evidência que o que Buñuel busca parece ser precisamente o que a teoria da informação deseja, a todo custo, evitar: o ruído.

Dessa perspectiva, os momentos mais significativos, no atinente às imagens, se definem em enxertos em que as forças do instinto estão presentes. Em cenas marcantes de filmes como Los Olvidados, Subida al cielo e The Young One, por citar alguns. Neles, a representação dos fenômenos naturais da morte, do sexo e da alimentação espeta as pupilas dos espectadores através de imagens inesperadas. Os enxertos, sempre situados no entremeio delas, são flashes em que a irracionalidade das pulsões descarrega parte da sua energia. Eles surgem quando menos se espera, mas sua irrupção parece ter uma finalidade bem definida: atentar contra atos de comunicação fortemente marcados pela informação e implantar as condições mínimas para que o ominoso ${ }^{15}$ se manifeste.

Tomo como paradigma desse processo o enxerto que aflora numa das seqüências mais instigantes de Le Journal d'une ferme de chambre (Figura 3). Aparece no entremeio das cenas em que a câmera descreve o passeio trágico da menina na floresta. A adolescente vai vestida à maneira de Chapeuzinho Vermelho e distraída com sua própria inocência. Ela procura caracóis naquele dia de inverno e os guarda numa cestinha de arame. Come frutinhos silvestres no instante em que se encontra com Joseph, a quem oferece um. Finalmente se adentra no mato e, depois de algumas alternâncias de planos da personagem e de animais selvagens, o corpo da menina surge inerte com as pernas cheias de sangue e os caracóis caminhando parcimoniosamente sobre suas coxas. Ao espectador lhe é negada qualquer informação sobre este desenlace, pois não há nenhum tipo de dado informativo que permita apontar com certeza qual o criminoso ou qual a causa da morte. As interrogações se instalam no enxerto e, na atmosfera de ambigüidade que dele emana, Joseph e o javali - um dos animais que participa da ação - se tornam suspeitos.

Para Victor Fuentes (2000: p.167), esta passagem arraiga na pulsão sexual e as metáforas - sendo a mais evidente a da babugem dos caracóis - que nela afloram serviriam muito bem para legitimar essa interpretação. Contudo, não me parece ser, para meus propósitos, os mais relevante neste momento, já que o que me importa é mos- 
trar que a continuidade decorrente da concatenação das imagens, responsável direta pelo relato, foi repentinamente rompida. E, com isso, criou-se a possibilidade de inserir na sequência outras probabilidades narrativas capazes de alterar os conteúdos da fábula central e, assim, deslocar as fontes de informação para colocar em seu lugar imagens pertencentes a um saber instintivo. Ou seja, imagens que possuem as características inerentes aos sentidos que antecedem à inervação. Algo semelhante ao que ocorreu com os enxertos de componentes acústicos já comentados ocorre também com os signos imagéticos. Por isso, minha inclinação se prende à idéia, defendida por Charles Tesson (1992: p. 263), de que existe no bestiário manipulado por Buñuel o desejo de colocar em questão "le mystère de la provenance". O desejo de buscar a origem e esse desejo se manifesta em suas constantes tentativas de expressar o inexpressável de coisas que são visíveis e não se podem ver ou de coisas que são audíveis e não se podem ouvir.

Em suma, os aspectos da sincronização que acabo de comentar mostram, de um lado, que as rupturas poéticas levadas a cabo por Buñuel no uso dos componentes sonoros privilegiam o aparecimento do ruído e, de outro, que as promovidas no campo das imagens favorecem a participação dos animais, domésticos ou não. Pode-se dizer que a junção de tais elementos produz efeitos de ambigüidade em que o ruído e a irracionalidade se apresentam como traços predominantes, como forças que se opõem às estruturas normativas sobre as quais assentam as ações dos relatos do cinema clássico. Além disso, a maneira de configurar esses rompimentos expressivo-semânticos caracteriza o que aqui se entende por poética do selvagem. 


\section{Bibliografia de Referência:}

ALIBERT, Jean-Louis. 2008. Le son de l'image. Paris: PUG.

AUB, Max. 1985. Conversaciones con Buñuel. Madrid: Aguilar.

BARTHES, Roland. 2002. Variaciones sobre la escritura.

Barcelona: Paidós,

BUÑUEL, Luis. 1998. Mi último suspiro. Barcelona:

Plaza \& Janés Editores.

CERVERA, Elena e Espada, Javier (comisarios). 2008.

Buñuel entre dos mundos, catálogo. México: SEACEX.

DROUZY, Maurice. 1978. Luis Buñuel Achitecte du Rêve.

Paris : Lherminier,

FREUD, Sigmund. 1993. Palabra y cosa. In: Obras Completas, volume XIV. Buenos Aires: Amorrortu Editores.

FREUD, Sigmund. 1993. Lo ominoso. In: Obras Completas, volume XVII. Buenos Aires: Amorrortu Editores.

FUENTES, Víctor. 2000. Los mundos de Buñuel. Madrid: Akal.

GROUPE 1. 1992. Traité du signe visuel. Paris: Seuil.

PEÑUELA CAÑIZAL, Eduardo. 2008. Imagens e Vestígios do Imemorável: uma leitura possível de Citizen Kane, in Monzani, Josette e Monzani, Luiz R. (orgs.): Imagem/ Memória, São Paulo: Pedro \& João Editores.

RICHY, John. 1999. How Marilyn Monroe Profoundly Influenced 'The Discreet Charme of the Bourgesoie', in Marsha Kinder (editor) Luis Buñuel's The Discreet Chame of the Bougeoisie. Cambridge: Cambridge University Press.

SÁNCHEZ VIDAL, Agustín. 1991. Luis Buñuel. Madrid : Cátedra.

TARANGER, Marie-Claude. 199o. Luis Buñuel. Le jeu et la loi. Paris : PUV

TESSON, Charles. 1992. Luis Buñuel. Paris: Cahiers de Cinéma, 1992. WU, Harmony H. 1999. Unraveling Entanglements of Sex, Narrative, Sound, and Gender : The Discreet Charme of 'Belle de Jour', in Marsha Kinder (editor) Luis Buñuel's The Discreet Chame of the Bougeoisie. Cambridge: Cambridge University Press, 1999. 